UDC 821.161.1.09 Saharov I. P. 821.161.1.09 Belinski V. G.

https://doi.org/10.18485/ms_zmss.2021.100.9

\author{
Андрей Топорков \\ Институт мировой литературы им. А. М. Горького РАН (Москва) \\ atoporkov@mail.ru
}

Andrey Toporkov

A. M. Gorky Institute of World Literature of the Russian Academy of Sciences atoporkov@mail.ru

\title{
ФОЛЬКЛОРНЫЕ МАТЕРИАЛЫ И. П. САХАРОВА В СТАТЬЯХ В. Г. БЕЛИНСКОГО О НАРОДНОЙ ПОЭЗИИ
}

\author{
FOLKLORE MATERIALS OF I. P. SAKHAROV \\ IN V. G. BELINSKY'S ARTICLES ON FOLK POETRY
}

В 1841 году увидели свет два издания, подготовленные Иваном Петровичем Сахаровым (1807-1863): Русские народные сказки и первый том Сказаний русского народа о семейной жизни своих предков. Известный литературный критик Виссарион Григорьевич Белинский (1811-1848) сначала написал восхищенные рецензии на эти издания, а потом использовал материалы Сахарова в своих статьях о народной поэзии. Только позднее стало известно, что Сахаров был фальсификатором: он сам сочинял сказки, которые выдавал за народное творчество, ссылался на несуществующие рукописи, правил тексты, которые передавали ему другие собиратели, и т. д. Белинский не знал всего этого и воспринял сборник Сахарова Pусские народные сказки как первое научное издание русских сказок. Статьи Белинского о народной поэзии много проиграли из-за того, что критик в ряде случаев в качестве примеров приводил не аутентичные фольклорные сказки, а стилизованные тексты, сочиненные Сахаровым.

Ключевые слова: Иван Петрович Сахаров, Виссарион Григорьевич Белинский, сказки, фольклор, литературная критика, рукопись.

Russian Folk Tales and the first volume of Tales of the Russian People about the Family Life of their ancestors prepared by Ivan Petrovich Sakharov (1807-1863) were published in 1841. The famous literary critic Vissarion Grigoryevich Belinsky (1811-1848) first wrote admiring reviews of these publications, and then used Sakharov's materials in his articles on folk poetry. It was only later that it became known that Sakharov was a forger: he himself composed fairy tales that he passed off as folk art, referred to non-existent manuscripts, corrected texts that were passed on to him by other collectors, etc. Belinsky did not know about that, and he accepted Sakharov's Russian Folk Tales as the first scientific publication of Russian fairy tales. Belinsky's articles on folk poetry lost a lot due to the fact that the critic in some cases cited as examples not authentic folk tales, but stylized texts composed by Sakharov.

Keywords: Ivan Petrovich Sakharov, Vissarion Grigoryevich Belinsky, fairy tales, folklore, literary criticism, manuscript. 
На рубеже 1830-1840-х гг. одно за другим выходили фольклорные издания, подготовленные Иваном Петровичем Сахаровым (1807-1863): Сказания русского народа о семейной жизни своих предков, Песни русского народа, Русские народные сказки. Книги имели значительный успех; читающей публике казалось, что в них по-новому открывались русская народность и родная старина. Среди тех, кто внимательно читал издания Сахарова и восхищался ими, был и литературный критик В. Г. Белинский (1811-1848).

При всех различиях между Сахаровым и Белинским есть некоторые параллели в траекториях их жизненного пути. Оба разночинцы из провинции, оба почти одновременно приехали в Москву, где учились в университете, правда на разных факультетах и с разными результатами: Сахаров в 1830-1835 гг. успешно закончил медицинский факультет, а Белинский в 1829-1832 гг. учился на словесном отделении философского факультета, три года оставался на первом курсе и позднее был отчислен, что не помешало ему стать литературным критиком. Оба в начале 1830 -х гг. начали публиковаться в журналах, а позднее переехали из Москвы в столицу: Сахаров в 1836 г. был переведен в Петербург на службу врачом в почтовый департамент Министерства внутренних дел, а Белинский в 1839 г. начал вести критический отдел журнала «Отечественные записки», который только что купил А. А. Краевский.

Литературную известность Сахарову принесли Сказания русского народа о семейной жизни своих предков, первая часть которых увидела свет в 1836 г., а вторая и третья - в 1837. В 1838-1839 гг. Сахаров издал Песни русского народа в пяти частях, а в 1841 г. - первую часть Сказок русского народа. Однако главным достижением Сахарова стал первый том нового издания Сказаний русского народа (1841), который включал четыре части и поразил современников своим фундаментальным характером.

Белинский был одним из первых, кто высоко оценил издания Сахарова. Позднее отношение к деятельности Сахарова изменилось до неузнаваемости. Сначала Аполлон Григорьев обвинил издателя Песен русского народа в искажении публикуемых им текстов (Григорьев 1854). Потом книги Сахарова подверглись сокрушительной критике П. А. Бессонова (Бессонов 1863: CXXIII-CXLIII). Красочный образ фальсификатора, сторонника «официальной народности» и ненавистника всего иностранного нарисован на страницах «Истории русской этнографии» А. Н. Пыпина (Пыпин 1891, 1: 276-313). Выяснилось, что Сахаров сам сочинял сказки, которые выдавал за народное творчество, делал републикации былин из сборника Кирши Данилова, выдавая их за тексты из вымышленной «рукописи Бельского», и т. д. Однако в 1841 г. вряд ли кто-нибудь догадывался о том, что представляют собой на самом деле сахаровские издания.

Некоторые книги, подготовленные Сахаровым, напоминают научные издания: помимо фольклорных текстов, в них имеются обширные предисловия и примечания, приводятся сравнительные материалы. В своих предисловиях Сахаров, как правило, ратовал за точность воспроизведения 
текстов, записанных изустно или скопированных с рукописей, а также упрекал других издателей песен и сказок, которые, по его утверждению, переиначивали, портили, уродовали публикуемые тексты. Требования к публикациям фольклора, которые выдвигал Сахаров, имели вполне обоснованный характер; другой вопрос, что сам он вовсе не следовал этим правилам.

В своих рецензиях на различные издания фольклора и его литературных переработок Белинский также выдвигал требования точной и адекватной передачи текстов и критиковал лубочную литературу; оценить же степень аутентичности материалов, публикуемых Сахаровым, критик не имел возможности. В результате сложилась несколько парадоксальная ситуация, при которой Белинский мог, ссылаясь на Сахарова, высказывать и вполне обоснованные соображения, и соображения совершенно ложные, цитировать из собраний Сахарова и аутентичные тексты (например, перепечатанные последним из сборника Кирши Данилова), и тексты, сочиненные самим Сахаровым на основе стилизации фольклора.

\section{Рецензии Белинского на издания Сахарова}

На рубеже 1830-1840-х гг. «Отечественные записки» довольно регулярно откликались на издания Сахарова. В 6 и 7 номерах журнала за 1839 год увидела свет обширная статья М. Н. Каткова, посвященная сахаровским Песням русского народа (Катков 1839). Эту статью Белинский внимательно прочитал еще в Москве и высоко оценил (Оксман 1958: 201). Во втором номере Отечественных записок за 1841 г. в разделе «Библиографическая хроника» появилось объявление о скором выходе нового издания Сказаний русского народа, а в четвертом номере уже сообщалось, что первый том увидел свет. В шестом номере были опубликованы друг за другом рецензии на первый том Сказаний русского народа и Русские народные сказки.

Обе рецензии напечатаны без подписи, тем не менее в собраниях сочинений Белинского они обычно включаются в основной корпус его сочинений. Хотя в литературе высказывались сомнения в том, что автором обеих рецензий является Белинский (Потявин 1956; Оксман 1958: 569), в комментариях к 9-томному собранию сочинений критика аргументирована традиционная атрибуция рецензий Белинскому (Белинский 1979, 4: 606).

Вторая рецензия следует в журнале непосредственно за первой и тематически примыкает к ней, начинаясь словами «Вот еще плод неутомимой деятельности почтенного И. П. Сахарова» (Белинский 1954, 5: 183). Рецензия на Русские народные сказки заканчивается обещанием написать вскоре в отделе «Критики» Отечественных записок статью о «Древних российских стихотворениях, собранных Киршею Даниловым» и там же обратиться опять «к вышедшему ныне первому тому Сказаний русского народа, и к первой части изданных г. Сахаровым Сказок, тем более что содержание большей части их сходно со стихотворениями сборника Кирши Данилова, находящимися там под теми же заглавиями» (Белинский 
1954, т. 5: 185). Речь идет о статьях Белинского о народной поэзии, опубликованных в следующих номерах Отечественных записок. Все это дополнительно подтверждает, что обе рецензии, как и статьи о народной поэзии, скорее всего также были написаны Белинским.

Можно также отметить, что в рецензиях высказываются некоторые наблюдения, которые более подробно обоснованы в статьях Белинского. Например, в рецензии на первый том Сказаний русского народа обсуждается вопрос о составителе Древних российских стихотворений:

«Говоря о сборнике древних песен, известном под названием: “Древние российские стихотворения, собранные Киршею Даниловым”, г. Сахаров решительно не признает, чтоб они были собраны этим казаком, а приписывает собрание их П. А. Демидову, “жившему в Туле в половине XVIII столетия и любившему собирать все редкости". Действительно, известно, что эти стихотворения открыты были П. А. Демидовым, что по смерти его достались они г. Хозикову, который подарил их Ф. П. Ключареву; что потом г. Ключарев поручил издать их А. Ф. Якубовичу и что они были изданы г-м Якубовичем в 1804 году, под названием: “Древние русские стихотворения. Потом К. Ф. Калайдович напечатал второе издание их в 1818 году, с той же рукописи, полученной им уже от графа Н. П. Румянцева, прибавив к ним 35 песен и сказок, откинутых г. Якубовичем. Но трудно доказать, чтоб именно П. А. Демидов собрал эти песни, а не кто-либо другой: пока для этого нет никаких данных, и представляемые г. Сахаровым доказательства — догадки, не более» (Белинский 1954, 5: 182).

О том же Белинский пишет в третьей статье о народной поэзии:

«Вообще, г. Сахаров обнаруживает к сборнику Кирши Данилова большую недоверчивость и даже что-то вроде неприязни. Это дело требует некоторого пояснения. Рукопись сборника Кирши Данилова была найдена г. Демидовым и издана (не вполне) г. Якубовичем в 1804 году, под титулом “Древние русские стихотворения". Потом рукопись перешла во владение графа Н. П. Румянцева, по поручению которого и издана была г. Калайдовичем в 1818 году, под титулом: “Древние российские стихотворения, собранные Киршею Даниловым и вторично изданные, с присовокуплением 35 песен и сказок, доселе неизвестных, и нот для напева”» (Белинский 1954, 5: 352).

Далее Белинский подробно излагает свой взгляд на личность Кирши Данилова как возможного составителя сборника и автора некоторых включенных в него песен (Белинский 1954, 5: 352-354). Таким образом, в данном случае Белинский открыто и развернуто полемизирует с Сахаровым. Стоит отметить, что документальные источники о существовании реального Кирши Данилова были обнаружены только во второй половине XX в. (Байдин 2015). Тогда и выяснилось, что в споре Белинского с Сахаровым первый был, несомненно, более прав.

В рецензии на первый том «Сказаний русского народа» автор с неподдельным восхищением объясняет, что именно так привлекает его в деятельности Сахарова: 
«Для тех из наших читателей, которые незнакомы еще с трудами г. Сахарова, скажем, что книга его есть сокровищница положительных сведений о разных фазах прежней русской жизни. Сведения эти или собраны им самим во время путешествий по губерниям Тульской, Калужской, Орловской, Рязанской и Московской, или доставлены ему просвещенными соотечественниками, или, наконец, заимствованы из книг, изданных другими. И. П. Сахаров - не теоретик: он даже иногда посмеивается над теориею, а иногда и побранивает ее, и потому не думайте встретить в его книге ни теоретических взглядов на ту или другую сторону русского быта, ни, так сказать, исторической архитектоники, ни попытки представить стройное изображение древней русской жизни; нет, г. Сахаров так добросовестен, что и не брался за подобное изображение; он лучше, чем кто-нибудь, знает, что это дело невозможное и что один только бесстыдный, достойный всякого презрения шарлатанизм может в великолепной программе обещать представить Россию во всевозможных видах и отношениях, - тогда как для этого нет ни у кого в мире ни сил, ни материалов... Он избрал себе часть истинно благую и истинно полезную: он собирает материалы - песни, сказки, поверья, предания, пословицы, обычаи, письменные памятники древности и, не мудрствуя лукаво, передает все это со всевозможною точностию и верностию своим соотечественникам. Мало этого: он тщательно собирает разные толки и мнения касательно спорных вопросов о достоверности того или другого ученого поверья и делает из этих мнений свод, ограничиваясь, по местам, легкими замечаниями с своей стороны и не входя в дальнейшее критическое разбирательство дела. Так и должно быть; в противном случае, книга его, имея две разносторонние цели, необходимо распалась бы на две части, из которых одна непременно вредила бы другой. Давайте нам материалов, фактов, больше фактов; критика не замедлит явиться, и тогда само собою обнаружится, кто прав, кто виноват - новая ли, все критизирующая историческая школа (которой явно противоречат убеждения почтенного И. П. Сахарова), или старая, готовая верить на слово и летописи, и “Слову о пълку Игореве”, и “Сказанию о Мамаевом побоище”, и “Слову Даниила Заточника”, и пр. и пр. Без фактов все дело будет вертеться только на словах, ограничиваться голословием. Итак, в сторону критику, почтенный и трудолюбивый наш собиратель “Сказаний русского народа”! Давайте нам фактов, больше фактов, — и вы услышите громкое спасибо всех сторон бесконечного царства русского» (Белинский 1954, 5: 180-181).

Белинский видит в Сахарове труженика, который «собирает материалы - песни, сказки, поверья, предания, пословицы, обычаи, письменные памятники древности и, не мудрствуя лукаво, передает все это со всевозможною точностию и верностию своим соотечественникам». Критик обращается к издателю с призывом: «Давайте нам фактов, больше фактов...». хотя на самом деле деятельность Сахарова меньше всего заключалась в публикации фактов.

Автор рецензии конспективно излагает содержание трех очерков, включенных в первую книгу Сказаний русского народа, под заглавием Русская народная литература: «Славяно-русская мифология», «Песни русского народа» и «Русские народные праздники». В каждом из этих очерков критически оцениваются источники и дается обзор литературы по назван- 
ным темам. Белинский присоединяется к суждениям Сахарова о недопустимой порче текстов в прежних изданиях песенников:

«Далее следуют “Песни русского народа”, или, лучше сказать, пересмотр почти всех доселе изданных песенников под различными, длинными и короткими, шарлатанскими и скромными названиями - от "Песенника", изданного Чулковым в 1770-м году, до новейших. Тут чрезвычайно любопытны сведения, собранные г-ном Сахаровым, о том, как смотрели прежние издатели на собираемые им песни, как поправляли их, то есть как коверкали и уничтожали весь колорит древности и народности для того, изволите видеть, чтоб представить их “в лучшем, привлекательнейшем виде”. Ужас объемлет душу, когда посмотришь на работу этих поправщиков, как иной, например, из 11 стихов чудного древнего стихотворения (из сборника Кирши Данилова) делал ровно 50, по правилам реторической “амплификации” <...>» (Белинский 1954, 5: 181; курсив В. Г. Белинского).

Собрание песен, помещенное в третьей книге Сказаний русского на$p o д a$, Белинский считает образцовым и рекомендует будущим издателям брать с Сахарова пример:

«Нельзя не иметь доверия к каждому стиху песен, сообщаемых г-м Сахаровым: везде слышится чисто народный склад, народное слово, народное выражение, и нигде незаметно ни малейшей подправки. Решительно собрание песен г-на Сахарова может быть названо у нас единственным и образцовым. Советуем всем собирателям поучиться у него этому делу» (Белинский 1954, 5: 183).

Говоря о четвертой книге Сказаний русского народа, озаглавленной Былины русских людей, Белинский отмечает:

«Четвертая книга содержит в себе перепечатанные с верных текстов “Былины русских людей”, именно: древние русские стихотворения, находящиеся в сборнике Кирши Данилова: “Добрыня Никитич”, “Илья Муромец”, “Василий Буслаев”, “Алеша Попович”, “Соловей Будимирович”, “Иван Гостиной сын” и “Чурила Пленкович” <...> (Белинский 1954, 5: 183).

Как известно, Сахаров перепечатал былины из сборника Кирши Данилова, выдавая их за тексты, якобы скопированные из вымышленной им «рукописи Бельского» (Бессонов 1863: CXXV-CXXVII). Белинский, хорошо знакомый со сборником Кирши Данилова, увидел у Сахарова те же тексты, и написал, что это «древние русские стихотворения, находящиеся в сборнике Кирши Данилова», которые, однако, перепечатаны не с издания 1818 г., а «с верных текстов».

Рецензия на первый том Сказаний русского народа заканчивается настоящим панегириком Сахарову:

«Честь и слава деятельности г-на Сахарова и любви его к избранному им предмету! Добросовестные, полезные и бескорыстные труды его не останутся без вознаграждения. Признательные соотечественники поощрят его своим вниманием, а ученые русские никогда не забудут трудов его, достав- 
ляющих им такие драгоценные, достоверные материалы, которых они нигде не нашли бы, если б г-н Сахаров, собиравший большую часть своих “Сказаний” на месте, в разных частях России, не делился с ними своими приобретениями» (Белинский 1954, т. 5: 183).

\section{Статьи Белинского о народной поэзии}

В 9, 11 и 12 номерах Отечественных записок за 1841 г. увидели свет четыре обширные статьи Белинского, представляющие собой развернутые отзывы на четыре издания: «Древние российские стихотворения, собранные Киршею Даниловым» (1818); «Древние русские стихотворения, служащие в дополнение к Кирше Данилову. Собранные М. Сухановым» (1840); «Сказания русского народа, собранные И. Сахаровым. Т. 1, кн. 1, 2, 3, 4» (1841) и «Русские народные сказки» того же Сахарова (1841). Эти статьи в изданиях сочинений Белинского печатаются под условным названием «Статьи о народной поэзии».

Белинский в своих статьях много писал о русских былинах, опираясь при этом на тексты из сборника Кирши Данилова. Подборку былин из этого сборника перепечатал и Сахаров в своих изданиях Песни русского народа (1839) и Сказания русского народа (1841). Хотя Сахаров утверждал при этом, что его былины якобы заимствованы из «рукописи Бельского», Белинский понимал, что Сахаров опубликовал те же самые тексты, которые критик хорошо знал и до этого по сборнику Кирши Данилова (Белинский 1954, 5: 351-352). Таким образом, Белинский в своих статьях использовал аутентичные русские былины, а к выдумкам Сахарова о том, что сборник Древние российские стихотворения, собранные Киршею Даниловым якобы был составлен П. А Демидовым в Туле, отнесся вполне критически (Белинский 1954, 5: 351-354).

Иная ситуация со сказками Сахарова, которые Белинский также использовал в своих статьях. Сам тип сборника Русские народные сказки наводил на мысль о научном характере этого издания. Помимо самих сказок, в сборнике имеется обширная вводная статья, которая включает 9 разделов, занимающих в целом 93 страницы: «Предисловие»; «Обозрение русских народных сказок»; «Список русским сказкам»; «Библиографическая роспись. І. Сказки, изданные без картин, книгами»; «Библиографическая роспись. II. Сказки, изданные с картинами, или лубочные издания»; «Лубочные изображения на листах»; «Издания русских сказок»; «Лубочные издания»; «Мнения русских писателей о народных сказках» (Сахаров 1841: III-XCV).

В заключительной части сборника, следующей за текстами сказок, имеются разделы «Сравнения» и «Примечания». В «Сравнениях» на 54 страницах приводятся выписки из опубликованных ранее сказок и былин; эти выписки призваны, по словам Сахарова, «доказать, как отважно прежние издатели сказок разрушали старину» (Сахаров 1841: 214). В кратких «Примечаниях» Сахаров сообщает о вымышленной им «рукописи Бельско- 
го» и предается самовосхвалению: «Все эти сказки, удержавшие вполне наш чистый народный язык, были приняты мною за основание текста. По крайней мере, доселе не видал ничего лучшего ни сам я, ни кто-либо другой» (Сахаров 1841: 270).

В предисловии к книге Сахаров критикует прежних издателей сказок за недобросовестное отношение к делу. По его словам, они публиковали «или сказки книжные, изуродованные поправками, или сказки самодельные, выдаваемые людьми безграмотными за старину стародавнюю» (Сахаров 1841: IV).

По утверждению Сахарова, для него было важно не только собрать русские сказки, но и освободить их тексты от уродующих их поправок, внесенных прежними издателями: «Надобно было собрать все наши сказки; надобно было пересмотреть, что в них есть чисто русского, что изуродованного поправками, что вновь выдуманного. Много было у нас предприятий, чтобы собрать и издать вполне русские сказки; но не много было людей, занимавшихся над ними со знанием дела» (Сахаров 1841: V).

Сахаров делал особый акцент на том, что при публикации сказок важно сохранить в неприкосновенности их язык: «Русские сказки, не поврежденные поправками, сохранившие вполне народный рассказ, составляют первостепенный источник для изучения нашего языка. Желание читать народные сказки на родном языке есть желание современное, сознаваемое в полном значении нашей народности» (Сахаров 1841: V-VI). И далее: «Я желал собрать народные сказки - чистые, не изуродованные поправками, сказки, рассказанные народным русским языком; а этого я не находил ни в сказках, изданных отдельными книгами, ни в самых лубочных изданиях» (Сахаров 1841: VI).

Сами по себе подобные высказывания имели вполне позитивную направленность. Проблема заключается только в том, что они совершенно не соответствовали издательской практике Сахарова.

Сборник Сахарова Русские народные сказки включает 6 текстов: «Добрыня Никитич», «Василий Буслаевич», «Илья Муромец», «Акундин», «О Ерше Ершове сыне Щетинникове» и «О семи Семионах, семи родных братьях». Из этих шести произведений только одно представляет собой сказку в современном понимании слова - «О семи Семионах, семи родных братьях».

Три текста, помещенные в начале Русских народных сказок, являются стилизациями, ориентированными одновременно на былины и сказки; условно их можно назвать «богатырскими сказками». В качестве материала при составлении этих текстов Сахаров использовал главным образом Древние российские стихотворения, собранные Киршею Даниловым (1818), Русские сказки В. А. Левшина (1780-1783) и лубочные издания сказок.

Первая «богатырская сказка» «Добрыня Никитич» представляет собой контаминацию «Повести о славном князе Владимире Киевском Солнушке Всеславьевиче и о сильном его могучем богатыре Добрыне Ники- 
тиче» В. А. Лёвшина и двух былин из Древних российских стихотворений: «Три года Добрынюшка стольничел» и «Алеша Попович». При этом «поскольку главным героем выведен Добрыня, ему приписаны былинные подвиги Алеши Поповича» (Корепова 2007: 168).

Вторая «богатырская сказка» «Василий Буслаевич» является переработкой былины «[Про] Василья Буслаева» из Древних российских стихотворений, а также «Повести о сильном богатыре и Старославенском Князе Василье Богуслаевиче» из сборника В. А. Лёвшина. Сюжет лёвшинской повести в целом совпадает с сюжетом былины, однако повесть при этом значительно больше по объему за счет более пространного стиля изложения и многочисленных диалогов. Нужно иметь в виду, что повесть В. А. Лёвшина о Василье Богуслаевиче значительно выделяется на общем фоне $P y c$ ских сказок, так как эта повесть наиболее близка былинам, сохраняет все основные былинные эпизоды, относительное лексическое единство и ритмику на протяжении всего повествования (Курышева 2009: 81-82). В тексте отсутствуют инородные вставки, каких немало в других произведениях В. А. Лёвшина.

Третья «богатырская сказка» «Илья Муромец» объединяет несколько сказочных и былинных эпизодов. В частности, используются былины «О станишниках или разбойниках» и «Первая поездка Ильи Муромца в Киев» из «Древних российских стихотворений» (Савченко 1914: 129-130; Соколов 1927: 308).

В статьях о народной поэзии Белинский сначала подробно излагает и анализирует былины о Добрыне Никитиче и Василии Буслаеве из сборника Кирши Данилова, а потом касается и сахаровских «богатырских сказок» «Добрыня Никитич» и «Василий Буслаевич», отмечая их отличия от соответствующих былин, разобранных им в предыдущей статье. Например, Белинский кратко пересказывает первую часть сахаровской сказки про Добрыню Никитича и, дойдя до второй части, сообщает: «Дальнейшие похождения Добрынюшки уже известны нашим читателям» (Белинский 1954, 5: 425). Несколько более подробно Белинский говорит о сахаровской «богатырской сказке» «Василий Буслаевич» (Белинский 1954, 5: 425-426).

Жанровую природу четвертого текста под названием «Акундин» из Русских народных сказок можно условно определить как «сказочная повесть». Источники этого текста далеко не очевидны. В примечаниях к нему Сахаров упомянул поэму Ф. Н. Глинки Карелия (1830): «Есть много сходного с нашею Сказкою в Олонецких народных преданиях. Любопытные могут видеть заметки об этом Акундине в примечаниях к стихотворению Ф. Н. Глинки: “Карелия”» (Сахаров 1841: 273). Отсылка Сахарова наводит на мысль, что в поэме Ф. Н. Глинки «Карелия, или заточение Марфы Иоанновны Романовой» есть какие-то сведения об Акундине, однако на самом деле о персонаже с таким именем в поэме не упоминается. Некоторую параллель к «Акундину» можно видеть только в описании змея Тугорина (Тугарина) и его гибели (Глинка 1830: 53-54). В «Акундине» тоже есть змей Тугарин, правда он лежит в реке Оке, а не в Онеге. 
В 1863 г. подробное сопоставление «Акундина» с Карелией произвел П. А. Бессонов, который пришел к выводу, что весь сюжет «Акундина» является перифразой сюжета Карелии и Жития Лазаря Муромского (Бессонов 1863: CXL-CXLII). Однако нам представляется, что П. А. Бессонов сильно преувеличил зависимость Сахарова от Ф. Н. Глинки. До какого-то нового исследования этого вопроса мы предпочитаем считать «Акундина» авторским произведением самого Сахарова, ориентированным одновременно на сказки, лубочные повести и былины.

В четвертой статье о народной поэзии Белинский обращается к сахаровскому «Акундину» после рассмотрения новгородских былин:

«Есть еще новогородское сказание, но это уже не поэма, а сказка, в которой новогородского - только герой. Мы говорим об “Акундине”, помещенном в первой части “Русских народных сказок”, изданных г. Сахаровым. Так как нам теперь, кончивши весь цикл богатырских поэм, должно сказать что-нибудь и о сказках, - то и кстати перейти прямо к “Акундину”. На этот раз мы ограничимся только общею характеристикою, не пускаясь в подробности. Акундин - богатырь в сказочном роде» (Белинский 1954, 5: 420-421).

Белинский пересказывает содержание «Акундина» и делает вывод:

«Эта сказка - целый роман; мы выжали из нее, так сказать, один сок и опустили множество подробностей, превосходно характеризующих общественный и семейный быт древней Руси. В этом отношении сказка “Акундин” имеет даже исторический интерес, - и г. Сахаров заслуживает особенной благодарности за спасение от забвения этого во всех отношениях любопытнейшего факта русской народной поэзии, русского духа и русского быта» (Белинский 1954, 5: 424).

Такая высокая оценка текста, сочиненного самим Сахаровым, конечно, является незаслуженной и свидетельствует о том, что Белинский принял псевдофольклорную стилизацию за аутентичное произведение.

\section{Фрагмент о народных сказках}

В 1844 г. Белинский написал фрагмент, посвященный народным сказкам, который был опубликован впервые в 1860 г. уже после смерти критика. Фрагмент предназначался для задуманной Белинским Критической истории русской литературы; в эту книгу в расширенном и переработанном виде должны были войти и его статьи о народной поэзии.

Белинский начинает с параллелей между былинами из Древних российских стихотворений и сказками из сборника Сахарова, которые он называет соответственно «богатырскими поэмами» и «богатырскими сказками»:

«Выше мы уже говорили о различии вообще поэм от сказок и в особенности русских богатырских поэм от русских богатырских сказок: поэма схватывает один какой-нибудь момент из жизни богатыря; сказка объемлет всю жизнь его; тон поэмы важнее, выше и поэтичнее; тон сказки простонароднее 
и прозаичнее. Мы уже говорили, что все поэмы, заключающиеся в сборнике Кирши Данилова, существовали и в форме сказок» (Белинский 1954, 5: 660).

Представление о том, что «все поэмы, заключающиеся в сборнике Кирши Данилова, существовали и в форме сказок», могло сложиться у Белинского под влиянием сборника Сахарова, в котором три первые сказки действительно отчасти воспроизводят сюжеты былин из «Древних российских стихотворений». Однако в целом это утверждение не выдерживает критики: далеко не все произведения из сборника Кирши Данилова известны и в виде сказок.

Вслед за Сахаровым, Белинский приводит сведения о количестве сказочных сюжетов, известных в России, и осуждает деятельность литераторов XVIII в. и издателей лубочных книг, искажавших сказочные тексты:

«Сказок на Руси множество. Г-н Сахаров насчитывает их до 120-ти названий, говоря только о тех из них, которые попали в печать. Сколько же их хранилось и еще теперь хранится в народной памяти? Но это богатство в сущности немногим разнится от совершенной нищеты: почти все эти сказки дошли до нас в искаженном виде, а бо́льшая часть и доселе сохранившихся в памяти народа еще не собрана. Не только наши литераторы прошлого века, но даже и простолюдины, занимавшиеся так называемыми лубочными изданиями, искажали их. Касательно этого предмета г. Сахаров сообщает весьма интересные подробности» (Белинский 1954, 5: 661).

Далее Белинский приводит из предисловия Сахарова обширную цитату, посвященную истории лубочных изданий (Белинский 1954, 5: 661662; Сахаров 1841: LXXI-LXXV).

Как известно, Сахаров особенно строго осуждал В. А. Лёвшина, у которого он сам заимствовал тексты. В частности, Сахаров писал: «Чулков знал подлинные тексты русских сказок, приводил из них буквальные выписки, и потом решился исправлять, переделывать и вновь свои составлять» (Сахаров 1841: LXIII)1. Почти в тех же словах В. А. Лёвшина упрекает и Белинский: «Чулков, еще в 1780 году начавший издавать "Русские сказки" и издавший их целых десять томов, имел подлинные списки этих сказок и, несмотря на то, почел необходимым исправлять и переделывать их» (Белинский 1954, т. 5: 662).

В отрывке о народных сказках Белинский приводит два текста из сборника Сахарова: подробно пересказывает сказку «О семи Семионах, семи родных братьях» и полностью перепечатывает «О Ерше Ершове сыне Щетинникове».

В основе текста сказки «О семи Семионах» лежит вариант, опубликованный ранее в сборнике Лекарство от задумчивости (1786), который 6 раз переиздавался между 1791 и 1839 гг. (Корепова 2007: 170; Корепова

1 Во времена Сахарова и Белинского сказки В. А. Левшина ошибочно приписывались авторству М. Д. Чулкова, поэтому упреки, которые высказываются Чулкову, на самом деле относятся к Лёвшину. 
2012: 209-217). При этом редакция Сахарова гораздо больше по своему размеру, чем сказка из Лекарства от задумчивости. Текст увеличился за счет прибавления одних эпизодов и разрастания других, введения многочисленных фольклорных или парафольклорных формул.

Белинский утверждал, что «сказка "О семи Семионах, семи родных братьях" носит на себе все признаки народной фантазии, или верно подслушанной из уст народа, или перепечатанной с хорошего старинного списка: это доказывает ее неподдельно народное выражение» (Белинский 1954, 5: 664). Именно язык сказки восхитил Белинского, хотя сахаровские стилизации позднее вызывали уничижительные оценки П. А. Бессонова, А. Н. Пыпина и других исследователей. В то же время о сюжете сказки Белинский отозвался несколько презрительно:

«Содержание этой сказки, оригинально-русское оно или восточного происхождения, во всяком случае так вздорно, что странно было бы рассуждать о нем; но выражение этой сказки, склад и тон рассказа, так наивны, так оригинальны, так проникнуты понятиями и взглядом на вещи той эпохи, в которую она сложена, и того класса народа, которым она сложена, что ее нельзя прочесть без интереса, более или менее живого. И этого-то не поняли ученые и образованные литераторы прошлого столетия: они гонялись за сюжетом сказок и ни во что ставили их форму, которую и позволяли себе переделывать, - тогда как в форме-то этих сказок и заключается весь их интерес, все их достоинство. Но не будем слишком винить этих переделывателей: они покорялись духу своего времени, которое требовало уже не сказок, а романов» (Белинский 1954, 5: 667-668).

В некотором противоречии с этой оценкой находится то, что сам Белинский в своей статье изложил сахаровскую редакцию сказки довольно лаконично, сократив многочисленные повторы и стилистические украшения, которые так любил Сахаров. В таком кратком пересказе на первый план выступил именно сюжет сказки, а стилевые особенности отошли на второй план.

Шестой текст сборника Русские народные сказки озаглавлен «О Ерше Ершове сыне Щетинникове» и представляет собой сатирическую повесть, широко известную в рукописной традиции. В качестве источника Сахаров на этот раз указал не мифическую «рукопись Бельского», а реальную рукопись, которая имелась в его собрании: «Сказка о Ерше Ершове сыне Щетинникове взята из рукописи, находящейся в моей библиотеке (смотри Отдел. III. Описание Славяно-Русских рукописей № 150)» (Сахаров 1841: 271). В одной из рукописей, принадлежавших Сахарову, действительно имелась сатирическая повесть о Ерше Ершове сыне Щетинникове; во 2-м издании каталога рукописей И. П. Сахарова она описана следующим образом: «№ 174. Сборник. Рукопись писана в 4 д. л. скорописью, в начале XVIII в., на 32 л. Содержит: 1 л. Сказка народная о Ерше Ершовиче» (Сахаров 184-?: 39). В настоящее время эта рукопись хранится в Государственном историческом музее в Москве, в собрании А. С. Уварова: «№ 1926 (135). Сборник. Конца XVII и нач. XVIII в.» (Леонид 1894, т. 4: 314-316). В тексте отсутствуют 
характерные черты сахаровского стиля; в целом он заметно отличается от остальных произведений, помещенных в Русских народных сказках. По-видимому, этот текст не подвергся какому-то существенному вмешательству Сахарова и опубликован в соответствии с рукописью. По классификации В. П. Адриановой-Перетц данный текст относится к первой редакции «Повести о Ерше Ершовиче». Рукопись из собрания А. С. Уварова учтена в текстологическом комментарии к публикации повести в известном издании Русская демократическая сатира XVII века (Адрианова-Перетц 1977: 145), однако не отмечено, что текст был опубликован Сахаровым.

\section{Некоторые выводы}

Таким образом, издания Сахарова Русские народные сказки и первый том Сказаний русского народа стали важными источниками статей Белинского о народной поэзии. Белинский проявил известную самостоятельность по отношению к суждениям Сахарова (например, в вопросе о личности Кирши Данилова), однако в целом он с доверием отнесся к публикациям Сахарова и активно использовал его издания как материал для своих суждений о фольклоре. Это неизбежно негативно сказалось на статьях Белинского, который цитировал сказки Сахарова, принимая их за аутентичный фольклор, однако не повлияло значительно на суждения Белинского о былинах, поскольку на самом деле былины, которые публиковал Сахаров, восходили не к мифической «рукописи Бельского», а к сборнику Кирши Данилова в издании 1818 г.

Белинский доверился декларациям Сахарова и воспринял Русские народные сказки как первое научное издание русских сказок. На словах отстаивая принцип буквального воспроизведения рукописных текстов, Сахаров на самом деле перерабатывал сказки и дополнял их фрагментами былин. Практика литературных переработок сказок имела в то время общераспространенный характер. Сахаров в этом смысле действовал так же, как многие издатели и до, и после него. Можно сказать, что Сахаров находился как бы на границе двух эпох: на уровне деклараций он обгонял свое время и выступал как ученые публикаторы второй половины XIX-XX века, a на уровне издательской практики - как публикаторы второй половины XVIII - первой половины XIX века., которые считали возможным контаминировать и перерабатывать тексты-источники.

Белинский вполне позитивно воспринял критику, которой Сахаров подвергал издателей песенников и лубочных сказок за их порчу текстовпротографов. Критик вряд ли мог догадаться о том, что и сам Сахаров обращается с текстами не лучше, чем его предшественники.

Поскольку Сахаров считал, что ему достались не аутентичные записи сказок, а их безвкусные переделки, он мог видеть свою миссию в том, чтобы вернуть этим произведениям их первоначальный вид. И если другие издатели, по мнению Сахарова, уродовали сказки, то сам он стремился вернуть им их изначальный вид. Другой вопрос, насколько удачными были 
его переделки и стилизации вне зависимости от того, что сам Сахаров явно был от них в полном восторге.

Если сравнить былины и сказки, которые Сахаров якобы извлек из пресловутой «рукописи Бельского», то открывается любопытная особенность этой вымышленной рукописи. Дело в том, что три былины имели те же названия, что и три сказки: «Добрыня Никитич», «Василий Буслаевич» и «Илья Муромец». При этом три былины в целом восходят к аутентичным текстам из Древних российских стихотворений, а «сказки» являются стилизациями, созданными самим Сахаровым отчасти на основе тех же самых былин.

Для того чтобы понять, зачем Сахарову понадобилось сближать былины и сказки, следует обратиться к его идеям, которые могут показаться современному читателю несколько абсурдными. Как ни странно, Сахаров полагал, что былины возникли на основе сказок, поэтому он представлял себе старинные сказки как некую смесь сказок и былин, а происхождение былин - как своеобразную кристаллизацию их текстов на основе «богатырских сказок». В частности, в статье «Былины русского народа» он писал:

«Всеми признано, что Русская народная поэзия, создавшая песни и сказки, происходит из одного источника - дум народных. <...> Поэзия песен, поэзия сказок есть одна и та же, потому что творчество произвело то и другое; но самые идеи и исполнения их указывают на резкие отличия. Сказки дошли до нас в мерной прозе, облеченные в формы поэтического языка. Песни с незапамятных времен являются в раздельных стихах. Из всех выводов открывается, что сказки предшествовали историческим песням. <...> В наших сказках сохраняются народные поэмы, исторические были, разные роды стихотворений, изданные гг. Якубовичем и Калайдовичем» (Сахаров 1839/3: XII-XIII).

Сочиняя своеобразные «богатырские сказки», Сахаров, по-видимому, пытался воссоздать некие прототексты былин, которые, по его мнению, должны были представлять собой своеобразную смесь фрагментов сказочных и былинных текстов.

В определенном смысле Белинский оказался заложником сахаровской стратегии мистификаций, его редакторской и издательской практики. Статьи Белинского о народной поэзии, конечно, много проиграли из-за того, что критик в ряде случаев цитировал гибридные стилизованные тексты, сочиненные Сахаровым.

\section{ЛИТЕРАТУРА}

Адрианова-Перетц Варвара (ред.) Русская демократическая сатира XVII века. Подгот. текстов, статья и коммент. В. П. Адриановой-Перетц. 2-е изд. доп. Москва: Наука, 1977. (Литературные памятники).

Байдин Виктор. Кирша Данилов в Сибири и на Урале: историко-биографические этюды. Екатеринбург: Издательство Уральского университета, 2015.

Белинский Виссарион. Полное собрание сочинений. В 13 т. Москва: Издательство Академии наук СССР, 1953-1959. 
Белинский Виссарион. Собрание сочинений. В 9 т. Москва: Художественная литература, 1976-1982.

Бессонов Петр. «Заметка». Песни, собранные П. В. Киреевским. Москва: Общество любителей российской словесности, 1863. Ч. 2. Песни былевые. Вып. 5: CXXIII-CXLIII.

Глинка Федор. Карелия, или Заточение Марфы Иоанновны Романовой: Описат. Стихотворение. В 4 ч. Санкт-Петербург: Непейцын, 1830.

Григорьев Аполлон. «Русские народные песни. Критический опыт». Москвитянин 15 (1854): 93-142 (Критика и библиография).

Катков Михаил. «Песни русского народа, изданные И. Сахаровым. Пять частей. Санкт-Петербург, 1838-1839». Отечественные записки 4/6-7 (1839): 1-92 (Критика).

[Кирша Данилов] Древния российския стихотворения, собранныя Киршею Даниловым, и вторично изданныя; С прибавлением 35 песен и сказок, доселе неизвестных, и нот для напева. Москва: В типографии Семена Селивановскаго, 1818.

Корепова Клара. «Комментарии». Русские народные сказки: Сборники Б. Бронницына и И. Сахарова. Санкт-Петербург: Тропа Троянова, 2007: 163-170.

Корепова Клара. Русская лубочная сказка. Москва: Форум, 2012.

Курышева Любовь. Повести о богатырях в «Русских сказках» В. А. Лёвшина: сказочноисторическая модель повествования. Новосибирск: Наука, 2009.

Левшин Василий. Руския сказки, содержащия древнейшия повествования о славных богатырях, сказки народныя, и прочия оставшиеся чрез пересказывание в памяти приключения. Ч. 1-10. Москва: Университетская типография, у Н. Новикова, 1780-1783.

Леонид (Кавелин Лев Александрович; архимандрит Троице-Сергиевой лавры). Cистематическое описание славяно-российских рукописей собрания графа А. С. Уварова, В 4 ч.: (Со включением 750 №№ собр. И. Н. Царского, опис. П. М. Строевым в алф. порядке). Ч. 1-4 / Сост. архим. Леонид. Москва: Товарищество типографии А. И. Мамонтова, 1893-1894.

Оксман Юлиан. Летопись жизни и творчества В. Г. Белинского. Москва: Государственное издательство художественной литературы, 1958, 641, [2] с.

Потявин Василий. «Мнимая рецензия Белинского на “Сказания русского народа" И. П. Сахарова». Ученые записки Ленинградского государственного университета. №229. Серия филологических наук. Вып. 30. 1957: 255-257.

Пыпин Александр. История русской этнографии. Т. 1-4. Санкт-Петербург: Типогафия М. М. Стасюлевича, 1890-1892.

Савченко Степан. Русская народная сказка: (История собирания и изучения). Киев: Типография Императорского Университета св. Владимира, 1914.

[Сахаров И. П.] Сказания русского народа, собранные И. Сахаровым. Т. 1. Кн. 1-4. 3-е изд. Санкт-Петербург: Типография Сахарова, 1841.

Сахаров Иван. Русские народные сказки. Ч. 1. Санкт-Петербург: тип. И. Сахарова, 1841.

[Сахаров И. П.] [Каталог рукописей библиотеки И. П. Сахарова. 2-е изд. Санкт-Петербург, 184 ?].

Соколов Борис. «Былины старинной записи». Этнография 2 (1927): 306-314.

\section{REFERENCES}

Adrianova-Peretc Varvara. (red.) Russkaya demokraticheskaya satira XVII veka. Podgot. tekstov, stat'ya i komment. V. P. Adrianovoj-Peretc. 2-e izd. dop. Moskva: Nauka, 1977. (Literaturnye pamyatniki).

Bajdin Viktor. Kirsha Danilov v Sibiri i na Urale: istoriko-biograficheskie etyudy. Ekaterinburg: Izdatel'stvo Ural'skogo universiteta, 2015.

Belinskij Vissarion. Polnoe sobranie sochinenij. V 13 t. Moskva: Izdatel'stvo Akademii nauk SSSR, 1953-1959.

Belinskij Vissarion. Sobranie sochinenij. V 9 t. Moskva: Hudozhestvennaya literatura, 1976-1982.

Bessonov Petr. «Zametka». Pesni, sobrannye P. V. Kireevskim. Moskva: Obshchestvo lyubitelej rossijskoj slovesnosti, 1863. Ch. 2. Pesni bylevye. Vyp. 5: CXXIII-CXLIII.

Glinka Fedor. Kareliya, ili Zatochenie Marfy Ioannovny Romanovoj: Opisat. Stihotvorenie. V $4 \mathrm{ch}$. Sankt-Peterburg: Nepejcyn, 1830. 
Grigor'ev Apollon. «Russkie narodnye pesni. Kriticheskij opyt». Moskvityanin 15 (1854): 93-142 (Kritika i bibliografiya).

Katkov Mihail. «Pesni russkogo naroda, izdannye I. Saharovym. Pyat ${ }^{\star}$ chastej. Sankt-Peterburg, 1838-1839». Otechestvennye zapiski 4/6-7 (1839): 1-92 (Kritika).

[Kirsha Danilov] Drevniya rossijskiya stihotvoreniya, sobrannyya Kirsheyu Danilovym, i vtorichno izdannyya; S pribavleniem 35 pesen i skazok, dosele neizvestnyh, i not dlya napeva. Moskva: V tipografii Semena Selivanovskago, 1818.

Korepova Klara. «Kommentarii». Russkie narodnye skazki: Sborniki B. Bronnicyna i I. Saharova. Sankt-Peterburg: Tropa Troyanova, 2007: 163-170.

Korepova Klara. Russkaya lubochnaya skazka. Moskva: Forum, 2012.

Kurysheva Lyubov'. Povesti o bogatyryah v «Russkih skazkah» V. A. Lyovshina: skazochno-istoricheskaya model ' povestvovaniya. Novosibirsk: Nauka, 2009.

Levshin Vasilij. Ruskiya skazki, soderzhashchiya drevnejshiya povestvovaniya o slavnyh bogatyryah, skazki narodnyya, i prochiya ostavshiesya chrez pereskazyvanie v pamyati priklyucheniya. Ch. 1-10. Moskva: Universitetskaya tipografiya, u N. Novikova, 1780-1783.

Leonid (Kavelin Lev Aleksandrovich; arhimandrit Troice-Sergievoj lavry). Sistematicheskoe opisanie slavyano-rossijskih rukopisej sobraniya grafa A. S. Uvarova. V 4 ch.: (So vklyucheniem 750 №№ sobr. I. N. Carskogo, opis. P. M. Stroevym v alf. poryadke). Sost. arhim. Leonid. Moskva: Tovarishchestvo tipografii A. I. Mamontova, 1893-1894.

Oksman Yulian. Letopis' zhizni i tvorchestva V. G. Belinskogo. Moskva: Gosudarstvennoe izdatel'stvo hudozhestvennoj literatury, 1958. 641, [2] s.

Potyavin Vasilij. «Mnimaya recenziya Belinskogo na "Skazaniya russkogo naroda" I. P. Saharova». Uchenye zapiski Leningradskogo gosudarstvennogo universiteta. № 229. Seriya filologicheskih nauk. Vyp. 30. 1957: 255-257.

Pypin Aleksandr. Istoriya russkoj etnografii. T. 1-4. Sankt-Peterburg: Tipogafiya M. M. Stasyulevicha, 1890-1892.

Savchenko Stepan. Russkaya narodnaya skazka: (Istoriya sobiraniya i izucheniya). Kiev: Tipografiya Imperatorskogo Universiteta sv. Vladimira, 1914.

[Saharov I. P.] Skazaniya russkogo naroda, sobrannye I. Saharovym. T. 1. Kn. 1-4. 3-e izd. SanktPeterburg: Tipografiya Saharova, 1841.

Saharov Ivan. Russkie narodnye skazki. Ch. 1. Sankt-Peterburg: tip. I. Saharova, 1841.

[Saharov I. P.] [Katalog rukopisej biblioteki I. P. Saharova. 2-e izd. Sankt-Peterburg, 184-?].

Sokolov Boris. «Byliny starinnoj zapisi». Etnografiya 2 (1927): 306-314.

Андреј Топорков

\author{
ФОЛКЛОРНИ МАТЕРИЈАЛИ И. П. САХАРОВА \\ У ЧЛАНЦИМА В. Г. БЕЛИНСКОГ О НАРОДНОЈ ПОЕЗИЈИ
}

Резиме

Године 1841. изашла су два издања која је приредио Иван Петрович Сахаров (18071863): Руске народне бајке и први том Предања руског народа о породичном животу предака. Чувени књижевни критичар Висарион Григорјевич Белински (1811-1848) испрва је на ова издања написао рецензије пуне дивљења, а потом је искористио Сахаровљева издања у својим чланцима о народној поезији. Тек касније се сазнало да је Сахаров био плагијатор: сам је писао бајке, које је представљао као народно стваралаштво, позивао се на непостојеће рукописе, преправљао текстове, које су му други колекционари давали итд. Белински није знао ништа од овога и гледао је на Сахаровљев зборник Руске народне бајке као на прво научно издање руских бајки. Чланци Белинског о народној поезији изгубили су много због чињенице да критичар у низу случајева као примере није наводио аутентичне фолклорне бајке, већ стилизоване текстове, које је писао Сахаров.

Кључне речи: Иван Петрович Сахаров, Висарион Григорјевич Белински, бајке, фолклор. 